\title{
CHEMICAL CONSTITUENTS OF SOME WELLS WATER IN SINAI (EGYPT) AND THEIR SUITABILITY OF QUALITY TO DIFFERENT USE ACTIVITIES
}

\author{
Shawn, M.M. * Azza R. Abdel Hamed** \\ * Oil Authority (Consultant in petroleum geology \& Hydrogeology) \\ ** Soils, Water \& Environment Res. Inst., ARC, Giza, Egypt.
}

\begin{abstract}
The study site of Wadi Sidri locates at west central Sinai, on the eastern side of the Suez Gulf. Wadi Sidri is considered one of the most important hydrographic basins in Sinai Peninsula because it receives, seasonally a considerable amounts of rainfall, most of it flows in the form of floods towards the Suez Gulf. Other amounts of these rainfalls are surface run off and catchment or stored as groundwater in a lot of wells amongst the area of study.
\end{abstract}

The present investigation aims at studing the chemical constituents of groundwater of the wells in Wadi Sidri, and to evaluate their suitability for irrigation or for other uses in different agriculture proposes; sharing in the development of the area. Chemical analysis for 21 ground water samples were collected from 21 selected wells from Sidri valley.

Data can be summarized as follow:

- Relatively use of groundwater in different human activities depend upon the general moderate values of $\mathrm{pH}$, TDS, SAR, $\mathrm{pHc}$ and adj $\mathrm{SAR}$ and adj $\mathrm{R}_{\mathrm{Na}}$.

- Hydro-chemical parameters intended that the determination of the ion ratios is important to distinguish between groundwater having pale salinity characteristics and those mineralized resulting by evaporation processes. The most important parameters are: $(\mathrm{Na}+\mathrm{K}) / \mathrm{Cl},\left(\mathrm{SO}_{4} / \mathrm{Cl}\right),(\mathrm{Ca} / \mathrm{Mg})$ and $(\mathrm{Na} /$ $\mathrm{K})$.

- The hypothetical salts assemblages in groundwater result from the combination between cations and anions. Groundwater of the studied wells reflect the existence of two assemblages salts of; $\mathrm{NaCl}, \mathrm{MgCl}_{2}, \mathrm{MgSO}_{4}$, $\mathrm{CaSO}_{4}$ and $\mathrm{Ca}\left(\mathrm{HCO}_{3}\right)_{2}$ beside to $\mathrm{NaCl}, \mathrm{Na}_{2} \mathrm{SO}_{4}, \mathrm{CaSO}_{4}, \mathrm{MgSO}_{4}$ and $\mathrm{Ca}$ $\left(\mathrm{HCO}_{3}\right)_{2}$.

- Many heavy and trace elements ( $\mathrm{Fe}, \mathrm{Mn}, \mathrm{Zn}, \mathrm{Cu}, \mathrm{Pb}$ and $\mathrm{Cd}$ ) are present in groundwater with low concentration (less than 0.1ppm), but sometimes much higher, particularly if the water has been in contact with mineralized rock or ore bodies.

Key Words: Sinai, Groundwater Quality, Chemical constituents, suitability INTRODUCTION

Development of Sinai Peninsula which represents approx. $6.10 \%$ of the total area of Egypt (about $61,000 \mathrm{Km}^{2}$ ) depends on the optimum

Fayoum J. Agric. Res. \& Dev., Vol. 30, No.2, July, 2016 
exploitation of all the existing water resources. The region, as all desert areas, characterized by scarce rainfall which represent the unique source of recharge to the existing previous rocks, and when exists, occasionally falls as short to heavy storms causing hazardous flash floods. Because of the importance of Sinai Peninsula in the plans of the Egyptian Government of Economic, Rehabilitation and Development, these areas must receive a great attention and more water (that is limited and precious under the prevailing arid conditions) will be needed. Therefore, efficient management to evaluate and exploiting the exiting groundwater in Sinai considered among the most serious challenge standing in the way of developing fferent localities and instilling urbanization communities in Sinai.

Wadi Sidri basin receive annually a considerable amount of rainfall on the heights, most of it flows as floods towards the Gulf of Suez. Furthermore, augmentation of infiltrating portion may increase groundwater storage and upgrade its quality. Great parts of rainfalls run off to drains to the Gulf of Suez, while the other part evaporates or percolates downward through the pore spaces and/ or fractures to feed the different wells. As stated by GSUS, (1998) and Hem (1989), the quality of groundwater is the resultant of many processes and reactions that have acted on the water through its movement from the precipitation rainfall on the ground surface and its infiltration \& movement through wells. The source of major cations, anions and metallic ions in groundwater resulted from weathering of the mother rocks and the leaching of the water bearing formation. Ayers and westcot (1976), SAR classes were no problem (less than 3), increasing problem (3 - 9), severe problem (higher than 9), and adj SAR depend the type of clay minerals, while adj $R_{\mathrm{Na}}$ depend upon the un-deposit calcium ions (me/l), where the partial pressure of $\mathrm{CO}_{2}$ was responsible on the deposition of calcium ions.

In wells unaffected by human activity, the quality of groundwater results from chemical reactions between the water and rock matrix as the water moves along flow paths from areas of recharge to areas of discharge (GSUS, 1998). In general, the longer groundwater remains in contact with soluble materials, the greater concentrations of dissolved materials in the water. The quality of groundwater also can change as the result of the mixing of waters from different wells. In wells affected by human activity, the quality of water can be directly affected by the infiltration of anthropogenic compounds.

Sidri basin is considered among the promising localities in west central Sinai; for tourism, agricultural trend for very local inhabitants, the mining activities, exciting land features as well as good soil cover. For these reasons, evaluate the groundwater quality for different uses in Sidri basin is great important, especially with respect to irrigation and other agriculture purposes.

This current study aims to study some chemical constituents of the

Fayoum J. Agric. Res. \& Dev., Vol. 30, No.2, July, 2016 
CHEMICAL CONSTITUENTS OF SOME WELLS.................... 136 existing wells. So, water samples from wells of Wadi Sidri were collected and chemically analyzed to diagnose their chemical constituents in order to evaluate their quality for different human activities.

\section{MATERIALS AND METHODS}

To achieve the aim of the current study i.e., studying the chemical constituents of groundwater for wells in Wadi Sidri, twenty one groundwater samples, denoted as "W1" to "W21", were collected from the existing wells, as the method of Rainwater and Thatcher (1960). The abscissas and some hydrogeologic data of the studied wells at Wadi Ssidri will be shown in Table

(1). The locations of wells in wadi sidri are shown in map (1).

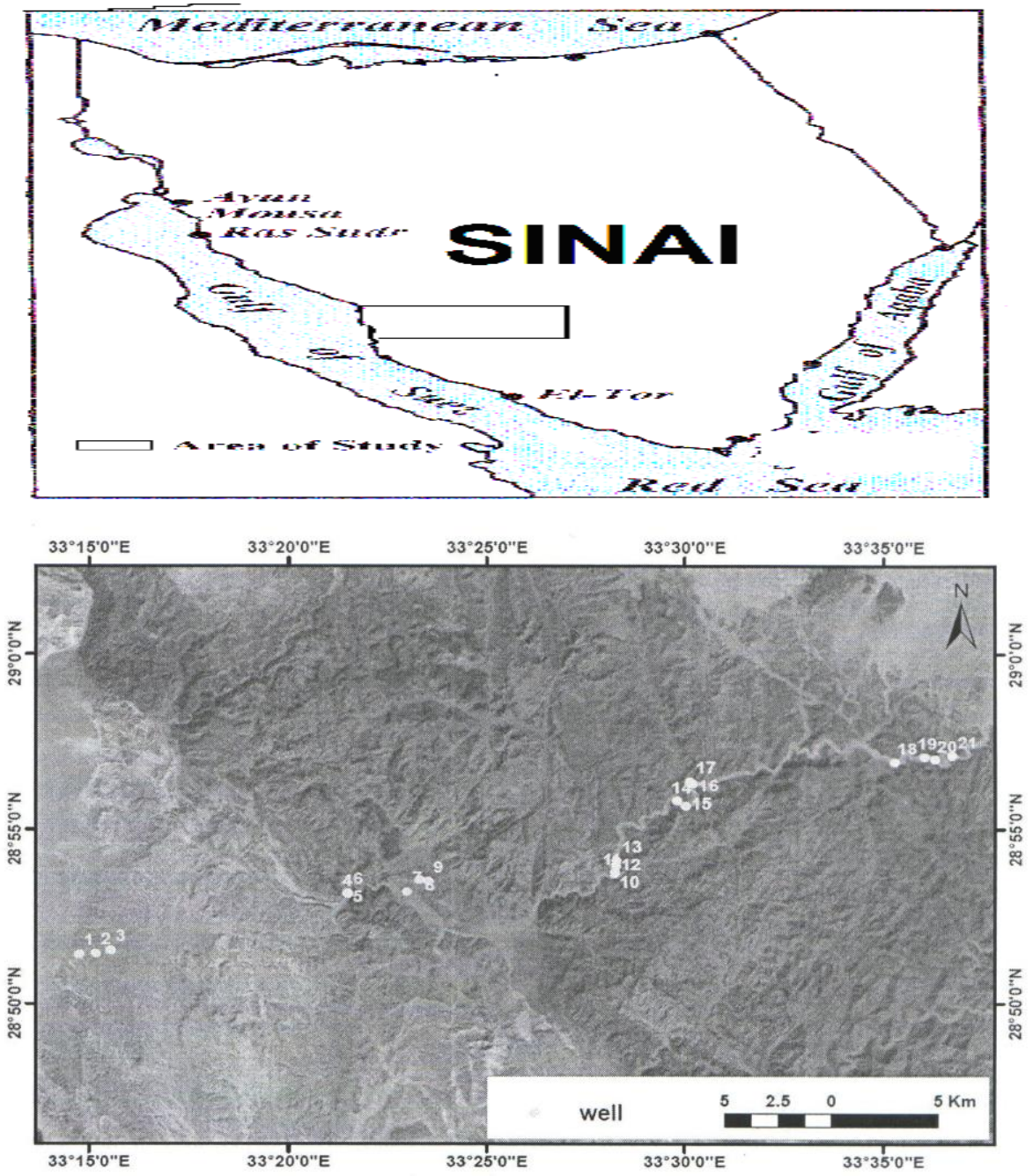

Map. (1): Locations of wells at Wade Sidri area.

Fayoum J. Agric. Res. \& Dev., Vol. 30, No.2, July, 2016 
Table (1):The abscissas and some hydrogeoloical data of the studied wells at Wade Sidri.

\begin{tabular}{|c|c|c|c|c|c|c|c|c|c|c|c|}
\hline \multirow[b]{2}{*}{$\begin{array}{c}\text { Basin } \\
\text { No }\end{array}$} & \multirow[b]{2}{*}{$\begin{array}{c}\text { Wells } \\
\text { No }\end{array}$} & \multicolumn{6}{|c|}{ Well abscissas } & \multirow{2}{*}{$\begin{array}{c}\text { Water } \\
\text { bearing } \\
\text { formation } \\
*\end{array}$} & \multirow{2}{*}{$\begin{array}{l}\text { Depth } \\
\text { to } \\
\text { water } \\
\text { (m) }\end{array}$} & \multirow{2}{*}{$\begin{array}{c}\text { Water } \\
\text { level } \\
\text { (from } \\
\text { sea } \\
\text { level) } \\
\text { (m) }\end{array}$} & \multirow{2}{*}{$\begin{array}{c}\text { Total } \\
\underset{(\text { m) }}{\text { depth }} \\
* *\end{array}$} \\
\hline & & DD $^{\circ}$ & $\mathbf{M M}^{\prime}$ & $\mathbf{S S}^{\prime \prime} \mathbf{N}$ & DD & $\mathbf{M M}^{\prime}$ & $\mathrm{SS}^{\prime \prime} \mathrm{E}$ & & & & \\
\hline \multirow{21}{*}{$\begin{array}{l}\text { Wadi } \\
\text { Sidri }\end{array}$} & 1 & 28 & 51 & 25.96 & 33 & 14 & 44.40 & A.D. & 26.25 & 57.75 & 70 \\
\hline & 2 & 28 & 51 & 28.00 & 33 & 15 & 10.00 & A. D. & 23.2 & 54.8 & 73 \\
\hline & 3 & 28 & 51 & 33.60 & 33 & 15 & 32.40 & A. D. & 24.5 & 58.0 & 73 \\
\hline & 4 & 28 & 53 & 08.45 & 33 & 21 & 29.87 & A. D. & 23.5 & 237.44 & 25 \\
\hline & 5 & 28 & 53 & \begin{tabular}{|l}
09.78 \\
\end{tabular} & 33 & 21 & 28.63 & A. D. & 25 & 236.21 & 26.5 \\
\hline & 6 & 28 & 53 & 11.45 & 33 & 21 & 28.84 & A. D. & 25.5 & 235.1 & 26 \\
\hline & 7 & 28 & 53 & 12.25 & 33 & 22 & 58.61 & S.S. & 33.5 & 251.79 & 48 \\
\hline & 8 & 28 & 53 & 31.37 & 33 & 23 & 17.61 & S.S. & 12.6 & 289.76 & 14 \\
\hline & 9 & 28 & 53 & 30.30 & 33 & 23 & 30.50 & S.S. & 45 & 255.84 & 60 \\
\hline & 10 & 28 & 53 & 42.53 & 33 & 28 & 14.08 & A. D. & 27.7 & 415.17 & 30 \\
\hline & 11 & 28 & 53 & 45.91 & 33 & 28 & 14.39 & A. D. & 27 & 414.35 & 29 \\
\hline & 12 & 28 & 53 & 58.20 & 33 & 28 & 16.11 & A. D. & 33.25 & 417.55 & 34.5 \\
\hline & 13 & 28 & 54 & 07.19 & 33 & 28 & 17.18 & A. D. & 31.5 & 429.66 & 33 \\
\hline & 14 & 28 & 55 & 48.43 & 33 & 29 & 48.64 & A. D. & 31.5 & 515.62 & 32 \\
\hline & 15 & 28 & 55 & 4048 & 33 & 30 & 01.98 & A. D. & 31 & 477.89 & 32.25 \\
\hline & 16 & 28 & 56 & 18.60 & 33 & 30 & 12.60 & A. D. & 33.5 & 491.37 & 35 \\
\hline & 17 & 28 & 56 & 22.50 & 33 & 30 & 08.40 & A. D. & 36 & 490.69 & 37 \\
\hline & 18 & 28 & 56 & 54.50 & 33 & 35 & 16.30 & G. & 26 & 622.61 & 28 \\
\hline & 19 & 28 & 27 & 04.04 & 33 & 36 & 02.49 & A. D. & 22 & 638.5 & 27 \\
\hline & 20 & 28 & 56 & 59.07 & 33 & 36 & $\begin{array}{ll}17.37 \\
\end{array}$ & G. & 22.7 & 644.2 & 24 \\
\hline & 21 & 28 & 57 & 05.57 & 33 & 36 & 43.80 & G. & 23 & 659.14 & 24.5 \\
\hline
\end{tabular}

(*) A.D. = Alluvial Deposits, S.S. = Sandstone, G. = Granite

(**) Total depth (m) : Drilling depth of the well until the first layer of water-bearing

The collected groundwater samples were stored in incubated glasses for chemical analyses. A complete chemical analysis of the groundwater samples has been done including the determination of $\mathrm{pH}$, salinity measured as total dissolved salts (TDS), (mg/L, i.e. $\mathrm{ppm})$ as Hem (1970), SAR, pHc, adj $\mathrm{SAR}, \operatorname{adj} \mathrm{R}_{\mathrm{Na}}$ as Ayers and Westcot (1994).

Also, the concentration of major cations, $\mathrm{Na}^{+}, \mathrm{K}^{+}, \mathrm{Ca}^{2+}, \mathrm{Mg}^{2+}$ and major anions, $\mathrm{Cl}^{-}, \mathrm{SO}_{4}{ }^{-}$and $\mathrm{HCO}_{3}{ }^{-}$as stated by Chapman and Pratt (1961) and expressed in milli-equivalent per liter $(\mathrm{m} . \mathrm{eq} / \mathrm{L})$. Some wells were chosen to determine ionic concentration of $\mathrm{Fe}, \mathrm{Mn}, \mathrm{Pb}, \mathrm{Cu}, \mathrm{Cd}$ and $\mathrm{Zn}$ of groundwater and expressed in milligrams per liter $(\mathrm{mg} / \mathrm{L}$, i.e. $\mathrm{ppm})$, using plasma 400 according to Soltanpour (1985).

Fayoum J. Agric. Res. \& Dev., Vol. 30, No.2, July, 2016 
CHEMICAL CONSTITUENTS OF SOME WELLS.

RESULTS AND DISCUSSION

Chemical composition and quality of the groundwater of wells:

The quality of groundwater is the resultant of all processes and reactions that have acted on the water through its movement from the precipitated rainfall on the ground surface and its infiltration and movement through wells.

Table (2) : Analytical data of ion concentrations as (m.eq/L) of water samples of the wells at Wadi Sidri .

\begin{tabular}{|c|c|c|c|c|c|c|c|c|c|c|}
\hline \multirow{3}{*}{ NO } & \multirow{3}{*}{$\mathbf{p H}$} & \multirow{3}{*}{ TDS g/l } & \multicolumn{8}{|c|}{ Ion concentration (meq/l) } \\
\hline & & & \multicolumn{4}{|c|}{ Cations } & \multicolumn{4}{|c|}{ Anions } \\
\hline & & & $\mathrm{Ca}^{2+}$ & $\mathbf{M g}^{2+}$ & $\mathrm{Na}^{+}$ & $\mathbf{K}^{+}$ & $\mathrm{CO}_{3}{ }^{2-}$ & $\mathrm{HCO}_{3}^{-}$ & $\mathrm{SO}_{4}{ }^{2-}$ & $\mathrm{Cl}^{-}$ \\
\hline 1 & 7.54 & 1.97 & 4.82 & 13.98 & 13.70 & 0.46 & 0.00 & 1.57 & 17.47 & 13.70 \\
\hline 2 & 7.47 & 1.75 & 7.73 & 9.06 & 12.07 & 0.56 & 0.00 & 1.56 & 12.91 & 14.63 \\
\hline 3 & 6.75 & 1.47 & 4.99 & 6.75 & 12.13 & 0.49 & 0.00 & 1.21 & 10.36 & 12.94 \\
\hline 4 & 7.19 & 1.13 & 6.85 & 2.50 & 9.12 & 0.26 & 0.00 & 2.22 & 8.41 & 7.68 \\
\hline 5 & 7.28 & 1.05 & 5.48 & 2.98 & 8.20 & 0.33 & 0.00 & 2.13 & 8.92 & 5.92 \\
\hline 6 & 7.28 & 1.22 & 8.10 & 3.28 & 8.26 & 0.26 & 0.00 & 2.18 & 9.99 & 7.67 \\
\hline 7 & 6.90 & 1.01 & 4.67 & 4.11 & 7.82 & 0.33 & 0.00 & 2.16 & 7.69 & 6.77 \\
\hline 8 & 7.70 & 2.46 & 6.99 & 6.99 & 27.02 & 0.36 & 0.00 & 2.38 & 12.67 & 25.94 \\
\hline 9 & 6.97 & 0.43 & 2.45 & 2.68 & 1.96 & 0.20 & 0.00 & 1.97 & 2.96 & 2.69 \\
\hline 10 & 7.85 & 1.42 & 8.93 & 3.70 & 10.36 & 0.38 & 0.10 & 1.27 & 10.10 & 11.72 \\
\hline 11 & 7.77 & 1.42 & 6.74 & 5.81 & 10.34 & 0.36 & 0.10 & 1.64 & 10.25 & 11.84 \\
\hline 12 & 7.21 & 1.44 & 5.89 & 7.81 & 10.53 & 0.33 & 0.00 & 1.88 & 10.01 & 12.15 \\
\hline 13 & 7.19 & 1.36 & 9.73 & 2.52 & 10.09 & 0.26 & 0.00 & 1.23 & $\begin{array}{l}8.89 \\
\end{array}$ & 12.10 \\
\hline 14 & 7.34 & 1.38 & 5.51 & 5.76 & 10.22 & 0.31 & 0.00 & 1.12 & 12.33 & 9.30 \\
\hline 15 & 7.70 & 1.24 & 6.24 & 5.32 & 8.94 & 0.26 & 0.00 & 1.82 & 10.19 & 8.28 \\
\hline 16 & 7.30 & 1.25 & 6.75 & 4.34 & 9.05 & 0.28 & 0.00 & 1.79 & 9.99 & 8.59 \\
\hline 17 & 7.19 & 1.26 & 6.81 & 5.43 & 8.98 & 0.26 & 0.10 & 1.99 & 9.40 & 9.10 \\
\hline 18 & 7.46 & 1.87 & 9.75 & 11.51 & 10.97 & 0.33 & 0.00 & 2.01 & 11.98 & 17.91 \\
\hline 19 & 7.19 & 1.54 & 7.29 & 9.13 & 9.78 & 0.28 & 0.00 & 2.35 & 11.01 & 12.55 \\
\hline 20 & 7.72 & 1.49 & 8.48 & 6.74 & 9.70 & 0.20 & 0.10 & 1.97 & 11.11 & 11.62 \\
\hline 21 & 7.22 & 3.38 & 26.20 & 20.56 & 12.96 & 0.36 & 0.00 & 1.53 & 14.86 & 43.11 \\
\hline
\end{tabular}

Therefore, ion concentrations as $(\mathrm{m} . \mathrm{eq} / \mathrm{L})$, will be used as basis to assessment the chemical constituents table (2) of groundwater of the studied wells. The analytical data of ion concentrations as well as total dissolved salts TDS and $\mathrm{pH}$ considered the most important parameters to assessment the groundwater quality, as well as SAR, PHc, adj SAR, and adj $\mathrm{R}_{\mathrm{Na}}$ Ayers and Westcot (1994), (Table, 3). Natural phenomena of the studied groundwater were normal, i.e. clear, colorless and odorless.

Fayoum J. Agric. Res. \& Dev., Vol. 30, No.2, July, 2016 
Shawn, M.M. * Azza R. Abdel Hamed**

Table (3): Calculated data comparison of $S A R$, Adj $R_{\mathrm{Na}}$ and Adj SAR.

\begin{tabular}{|c|c|c|c|c|c|c|c|}
\hline $\begin{array}{c}\text { Basin } \\
\text { No }\end{array}$ & $\mathbf{S A R}$ & $\begin{array}{c}\mathbf{E C} \\
(\boldsymbol{\mu m h o / c m})\end{array}$ & $\begin{array}{c}\mathbf{H C O}_{\mathbf{3}} / \mathbf{C a} \\
*\end{array}$ & $\begin{array}{c}\mathbf{C a x} \\
* *\end{array}$ & $\mathbf{A d j}_{\mathbf{N a}}$ & $\mathbf{P H c}$ & $\begin{array}{c}\text { Adj } \\
\mathbf{S A R}\end{array}$ \\
\hline 1 & 4.47 & 3.25 & 0.36 & 4.72 & 4.48 & 7.2 & 9.83 \\
\hline 2 & 4.17 & 2.74 & 0.20 & 6.86 & 4.28 & 7.3 & 8.75 \\
\hline 3 & 5.01 & 2.74 & 0.24 & 5.91 & 4.82 & 7.5 & 9.51 \\
\hline 4 & 4.22 & 1.83 & 0.32 & 4.98 & 4.72 & 7.4 & 8.44 \\
\hline 5 & 3.97 & 1.79 & 0.39 & 4.11 & 4.36 & 7.4 & 7.97 \\
\hline 6 & 3.46 & 1.81 & 0.27 & 4.98 & 3.92 & 7.3 & 7.27 \\
\hline 7 & 3.73 & 1.75 & 0.46 & 3.68 & 3.93 & 7.4 & 7.46 \\
\hline 8 & 10.22 & 4.18 & 0.34 & 4.91 & 10.54 & 7.35 & 20.95 \\
\hline 9 & 1.22 & 0.86 & 0.80 & 2.51 & 1.22 & 7.55 & 2.26 \\
\hline 10 & 4.12 & 2.36 & 0.14 & 7.90 & 4.30 & 7.4 & 8.25 \\
\hline 11 & 4.13 & 2.35 & 0.24 & 5.62 & 4.33 & 7.4 & 8.26 \\
\hline 12 & 4.02 & 2.41 & 0.32 & 4.98 & 4.16 & 7.3 & 8.45 \\
\hline 13 & 4.08 & 2.42 & 0.13 & 7.90 & 4.42 & 7.5 & 7.75 \\
\hline 14 & 4.31 & 2.14 & 0.20 & 6.52 & 4.12 & 7.55 & 7.96 \\
\hline 15 & 3.72 & 2.02 & 0.29 & 4.98 & 3.94 & 7.35 & 7.62 \\
\hline 16 & 3.84 & 2.06 & 0.27 & 4.98 & 4.06 & 7.4 & 7.69 \\
\hline 17 & 3.63 & 2.05 & 0.29 & 4.98 & 3.94 & 7.3 & 7.62 \\
\hline 18 & 3.36 & 3.27 & 0.21 & 6.86 & 3.62 & 7.1 & 7.74 \\
\hline 19 & 3.41 & 8.64 & 0.32 & 6.04 & 3.55 & 7.1 & 7.85 \\
\hline 20 & 3.52 & 2.60 & 0.23 & 5.91 & 3.86 & 7.2 & 7.74 \\
\hline 21 & 2.68 & 6.15 & 0.06 & 19.07 & 2.91 & 6.9 & 6.70 \\
\hline
\end{tabular}

* $\quad \mathrm{HCO}_{3} / \mathrm{Ca}=$ calculated from $\mathrm{HCO}_{3}$ and $\mathrm{Ca}$ from table (2)

** $\quad$ Cax $=$ calculated from table (4)

The adjusted Sodium Adsorption Ratio (adj SAR) is calculated from the following equation and table (2) Ayers and Westcot (1994)

$$
\begin{gathered}
\operatorname{adj} \boldsymbol{S A R}=\boldsymbol{S A R}(\mathbf{1}+(\mathbf{8 . 4}-\boldsymbol{p H C})) \\
p H c=(p K 2-p K c)+p(C a+M g)+p(A l k)
\end{gathered}
$$

Whereas the values of $(\mathrm{pK} 2-\mathrm{pKc}), \mathrm{P}(\mathrm{ca}+\mathrm{Mg})$ and $\mathrm{P}(\mathrm{Alk})$ were obtained from special table (Ayers and Westcot, 1976) opposite to the concentration (me/l) of $(\mathrm{Ca}+$ $\mathrm{Mg}+\mathrm{Na}),(\mathrm{Ca}+\mathrm{Mg})$ and $\left(\mathrm{CO}_{3}+\mathrm{HCO}_{3}\right)$ me/l from table (2), respectively.

The adjusted Sodium Adsorption Ratio for $\mathrm{Ca}_{\mathrm{x}}\left(\operatorname{adj} \mathrm{R}_{\mathrm{Na}}\right)$ can be calculated from the following equation and the following and table (2) Ayers and Westcot (1994)

$$
\operatorname{adjR}_{N a}=\frac{N a}{\sqrt{\frac{C a_{x}+M g}{2}}}
$$

Where: $\mathrm{Na}=$ sodium in the irrigation water reported in me/l

Fayoum J. Agric. Res. \& Dev., Vol. 30, No.2, July, 2016 
CHEMICAL CONSTITUENTS OF SOME WELLS..................... 140

$\mathrm{Ca}_{\mathrm{x}}=\mathrm{a}$ modified calcium value taken from Table (4), reported in $\mathrm{me} / \mathrm{l} . \mathrm{Ca}_{\mathrm{x}}$ represents $\mathrm{Ca}$ in the applied irrigation water but modified due to salinity of the applied water $\left(\mathrm{EC}_{\mathrm{w}}\right)$, its $\mathrm{HCO}_{3} / \mathrm{Ca}$ ratio $\left(\mathrm{HCO}_{3}\right.$, and $\mathrm{Ca}$ in me/l) and the estimated partial pressure of $\mathrm{CO}_{2}$ in the surface few millimeters of soil $\left(\mathrm{PcO}_{2}=0.0007\right.$ atmospheres)

$\mathrm{Mg}=$ magnesium in the irrigation water reported in me/l.

Table (4): Calcium concentration $\left(C a_{x}\right)$ expected to remain in nearsurface soil-water following irrigation with water of given $\mathrm{HCO}_{3} / \mathrm{Ca}$ ratio and $\mathrm{EC}_{\mathrm{w}}$.

\begin{tabular}{|c|c|c|c|c|c|c|c|c|c|c|c|c|c|}
\hline \multicolumn{14}{|c|}{ Salinity of applied water $\left(E C_{w}\right)(d S / m)$} \\
\hline & & 0.1 & 0.2 & 0.3 & 0.5 & 0.7 & 1.0 & 1.5 & 2.0 & 3.0 & 4.0 & 6.0 & 8.0 \\
\hline \multirow{27}{*}{$\begin{array}{l}\text { Ratio of } \\
\mathrm{HCO}_{3} / \mathrm{Ca}\end{array}$} & .05 & 13.20 & 13.61 & 13.92 & 14.40 & 14.79 & 15.26 & 15.91 & 16.43 & 17.28 & 17.97 & 19.07 & 19.94 \\
\hline & .10 & 8.31 & 8.57 & 8.77 & 9.07 & 9.31 & 9.62 & 10.02 & 10.35 & 10.89 & 11.32 & 12.01 & 12.56 \\
\hline & .15 & \begin{tabular}{|l|l}
6.34 \\
\end{tabular} & 6.54 & 6.69 & 6.92 & 7.11 & 7.34 & 7.65 & 7.90 & 8.31 & 8.64 & 9.17 & 9.58 \\
\hline & .20 & 5.24 & 5.40 & 5.52 & 5.71 & 5.87 & 6.06 & 6.31 & 6.52 & 6.86 & 7.13 & 7.57 & 7.91 \\
\hline & .25 & 4.51 & 4.65 & 4.76 & 4.92 & 5.06 & 5.22 & 5.44 & 5.62 & 5.91 & 6.15 & 6.52 & 6.82 \\
\hline & .30 & 4.00 & 4.12 & 4.21 & 4.36 & 4.48 & 4.62 & 4.82 & 4.98 & 5.24 & 5.44 & 5.77 & 6.04 \\
\hline & .35 & 3.61 & 3.72 & 3.80 & 3.94 & 4.04 & 4.17 & 4.35 & 4.49 & 4.72 & 4.91 & 5.21 & 5.45 \\
\hline & .40 & 3.30 & 3.40 & 3.48 & 3.60 & 3.70 & 3.82 & 3.98 & 4.11 & 4.32 & 4.49 & 4.77 & 4.98 \\
\hline & .45 & 3.05 & 3.14 & 3.22 & 3.33 & 3.42 & 3.53 & 3.68 & 3.80 & 4.00 & 4.15 & 4.41 & 4.61 \\
\hline & .50 & 2.84 & 2.93 & 3.00 & 3.10 & 3.19 & 3.29 & 3.43 & 3.54 & 3.72 & 3.87 & 4.11 & 4.30 \\
\hline & .75 & 2.17 & 2.24 & 2.29 & 2.37 & 2.43 & 2.51 & 2.62 & 2.70 & 2.84 & 2.95 & 3.14 & 3.28 \\
\hline & 1.00 & \begin{tabular}{|l|}
1.79 \\
\end{tabular} & 1.85 & 1.89 & 1.96 & 2.01 & 2.09 & 2.16 & 2.23 & 2.35 & 2.44 & 2.59 & 2.71 \\
\hline & 1.25 & 1.54 & 1.59 & 1.63 & 1.68 & 1.73 & 1.78 & 1.86 & 1.92 & 2.02 & 2.10 & 2.23 & 2.33 \\
\hline & 1.50 & 1.37 & 1.41 & 1.44 & 1.49 & 1.53 & 1.58 & 1.65 & 1.70 & 1.79 & 1.86 & 1.97 & 2.07 \\
\hline & 1.75 & 1.23 & 1.27 & 1.30 & 1.35 & 1.38 & 1.43 & 1.49 & 1.54 & 1.62 & 1.68 & 1.78 & 1.86 \\
\hline & 2.00 & 1.13 & 1.16 & 1.19 & 1.23 & 1.26 & 1.31 & 1.36 & 1.40 & 1.48 & 1.54 & 1.63 & 1.70 \\
\hline & 2.25 & 1.04 & 1.08 & 1.10 & 1.14 & 1.17 & 1.21 & 1.26 & 1.30 & 1.37 & 1.42 & 1.51 & 1.58 \\
\hline & 2.50 & 0.97 & 1.00 & 1.02 & 1.06 & 1.09 & 1.12 & 1.17 & 1.21 & 1.27 & 1.32 & 1.40 & 1.47 \\
\hline & 3.00 & 0.85 & 0.89 & 0.91 & 0.94 & 0.96 & 1.00 & 1.04 & 1.07 & 1.13 & 1.17 & 1.24 & 1.30 \\
\hline & 3.50 & 0.78 & 0.80 & 0.82 & 0.85 & 0.87 & 0.90 & 0.94 & 0.97 & 1.02 & 1.06 & 1.12 & 1.17 \\
\hline & 4.00 & 0.71 & 0.73 & 0.75 & 0.78 & 0.80 & 0.82 & 0.86 & 0.88 & 0.93 & 0.97 & 1.03 & 1.07 \\
\hline & 4.50 & 0.66 & 0.68 & \begin{tabular}{|l|}
0.69 \\
\end{tabular} & 0.72 & 0.74 & 0.76 & 0.79 & 0.82 & 0.86 & 0.90 & 0.95 & 0.99 \\
\hline & 5.00 & 0.61 & 0.63 & 0.65 & 0.67 & 0.69 & 0.71 & 0.74 & 0.76 & 0.80 & 0.83 & 0.88 & 0.93 \\
\hline & 7.00 & 0.49 & 0.50 & 0.52 & 0.53 & 0.55 & 0.57 & 0.59 & 0.61 & 0.64 & 0.67 & 0.71 & 0.74 \\
\hline & 10.00 & 0.39 & 0.40 & 0.41 & 0.42 & 0.43 & 0.45 & 0.47 & 0.48 & 0.51 & 0.53 & 0.56 & 0.58 \\
\hline & 20.00 & 0.24 & 0.25 & 0.26 & 0.26 & 0.27 & 0.28 & 0.29 & 0.30 & 0.32 & 0.33 & 0.35 & 0.37 \\
\hline & 30.00 & 0.18 & 0.19 & 0.20 & 0.20 & 0.21 & 0.21 & 0.22 & 0.23 & 0.24 & 0.25 & 0.27 & 0.28 \\
\hline
\end{tabular}

Adapted from Suarez (1981).

** Assumes a soil source of calcium from lime $\left(\mathrm{CaCO}_{3}\right)$ or silicates; no precipitation of magnesium, and partial pressure of $\mathrm{CO}_{2}$ near the soil surface $\left(\mathrm{P}_{\mathrm{CO} 2}\right)$ is .0007 atmospheres.

*** $\mathrm{Ca}_{\mathrm{x}}, \mathrm{HCO}_{3}, \mathrm{Ca}$ are reported in $\mathrm{me} / \mathrm{l} ; \mathrm{EC}_{\mathrm{w}}$ is in $\mathrm{dS} / \mathrm{m}$.

Data calculated in table (3) for SAR, adj $R_{\mathrm{Na}}$ and adj SAR showed that

Fayoum J. Agric. Res. \& Dev., Vol. 30, No.2, July, 2016 
adj $\mathrm{R}_{\mathrm{Na}}$ equal one fold of SAR and adj SAR showed two folds of SAR. These mean that adj $R_{\mathrm{Na}}$ more reliable for irrigation water.

\section{Chemical Parameters:}

The relationships between the different major ions could be studied through the determination of the ion ratios. These ratios are helpful in detecting the hydro-chemical processes affecting water quality such as mixing, leaching and ion exchange. Also these ratios are useful in comparing water from different sources or reservoirs. On the same time the use of such ratios is important to distinguish between groundwater having pale salinity characteristics and those mineralized resulting by evaporation processes. Table (5) shows the hydro-chemical parameters in the groundwater of the studied wells based on the analytical data in Table (2). Discussions of some common parameters are given below.

1. $(\mathbf{N a}+\mathbf{K})$ / Cl: This parameter is of special importance, it gives an indication about the water origin (marine or fresh water). In sea water it ranges between 0.85 and 0.87 , while in the fresh meteoric water it is more than unity.

Table (5) : Hydro-chemical parameters in groundwater of wells in Wadi Sidri.

\begin{tabular}{|c|c|c|c|c|c|c|c|}
\hline Well No & $\mathbf{( N a + K ) / C l}$ & $\mathbf{C a} / \mathbf{C l}$ & $\mathbf{C a} / \mathbf{M g}$ & $\mathbf{S O 4} / \mathbf{C l}$ & $\mathbf{N a} / \mathbf{K}$ & $\mathbf{M g} / \mathbf{C l}$ & $\mathbf{C l} / \mathbf{H C O}_{\mathbf{3}}$ \\
\hline 1 & 1.03 & 0.35 & 0.34 & 1.28 & 29.78 & 1.02 & 8.73 \\
\hline 2 & 0.86 & 0.53 & 0.85 & 0.88 & 21.55 & 0.62 & 9.38 \\
\hline 3 & 0.98 & 0.39 & 0.74 & 0.80 & 24.76 & 0.52 & 10.69 \\
\hline 4 & 1.22 & 0.89 & 2.74 & 1.10 & 35.08 & 0.33 & 3.46 \\
\hline 5 & 1.44 & 0.93 & 1.84 & 1.51 & 24.85 & 0.50 & 2.78 \\
\hline 6 & 1.11 & 1.06 & 2.47 & 1.30 & 31.77 & 0.43 & 3.52 \\
\hline 7 & 1.20 & 0.69 & 1.14 & 1.14 & 23.70 & 0.61 & 3.13 \\
\hline 8 & 1.06 & 0.27 & 1.00 & 0.49 & 75.06 & 0.27 & 10.90 \\
\hline 9 & 0.80 & 0.91 & 0.91 & 1.10 & 9.80 & 1.00 & 1.37 \\
\hline 10 & 0.92 & 0.76 & 2.41 & 0.86 & 27.26 & 0.32 & 9.23 \\
\hline 11 & 0.90 & 0.57 & 1.16 & 0.87 & 28.72 & 0.49 & 7.22 \\
\hline 12 & 0.89 & 0.48 & 0.75 & 0.82 & 31.91 & 0.64 & 6.46 \\
\hline 13 & 0.86 & 0.80 & 3.86 & 0.73 & 38.81 & 0.21 & 9.84 \\
\hline 14 & 1.13 & 0.59 & 0.96 & 1.33 & 32.97 & 0.62 & 8.30 \\
\hline 15 & 1.11 & 0.75 & 1.17 & 1.23 & 34.38 & 0.64 & 4.55 \\
\hline 16 & 1.09 & 0.79 & 1.56 & 1.16 & 32.32 & 0.51 & 4.80 \\
\hline 17 & 1.02 & 0.75 & 1.25 & 1.03 & 34.54 & 0.60 & 4.57 \\
\hline 18 & 0.63 & 0.54 & 0.85 & 0.67 & 33.24 & 0.64 & 8.91 \\
\hline 19 & 0.80 & 0.58 & 0.80 & 0.88 & 34.93 & 0.73 & 5.34 \\
\hline 20 & 0.85 & 0.73 & 1.26 & 0.96 & 48.50 & 0.58 & 5.90 \\
\hline 21 & 0.31 & 0.61 & 1.27 & 0.34 & 36.00 & 0.48 & 28.18 \\
\hline
\end{tabular}

2. $\mathrm{SO}_{4}$ / Cl: This ratio is useful as a guide for detecting any excess in sulphate content in the groundwater due to dissolution of calcium sulphate or precipitation of calcium carbonate.

Fayoum J. Agric. Res. \& Dev., Vol. 30, No.2, July, 2016 
CHEMICAL CONSTITUENTS OF SOME WELLS.

3. $\mathbf{C a} / \mathbf{M g}: \mathrm{Ca} / \mathrm{Mg}$ value in some wells is more than 0.9 where the waterbearing sediments are mainly of sands. In the other wells $\mathrm{Ca} / \mathrm{Mg}$ value is less than 0.9, where there is an increase in $\mathrm{Ca}$ ions content which resulted from the precipitation of calcium carbonate or calcium sulphate.

4. Na / K: When the ratio $\mathrm{Na} / \mathrm{K}$ is more than 50 in the wells it is due to the long pass between these wells and the recharging sources. On the other hand, when this ratio is less than 50 it is indicated that these wells are near from the recharging sources.

\section{Hypothetical Salts Assemblages:}

Generally, the hypothetical salts assemblages in groundwater result from the combination between cations and anions. The groundwater of the studied wells reveals different salt assemblages reflecting the geologic and geomorphologic impacts. The studied samples of groundwater reflect the existence of three assemblages of:

1) The first assemblage comprises of: $\mathrm{NaCl}, \mathrm{MgCl}_{2}, \mathrm{MgSO}_{4}, \mathrm{CaSO}_{4}$ and $\mathrm{Ca}$ $\left(\mathrm{HCO}_{3}\right)_{2}$ characterizes the water of samples of wells (W2, W3, W9,W10, W11, W12, W13, W17, W18,W19 andW20).

2) The second assemblage comprises of: $\mathrm{NaCl}, \mathrm{Na}_{2} \mathrm{SO}_{4}, \mathrm{CaSO}_{4}, \mathrm{MgSO}_{4}$ and $\mathrm{Ca}\left(\mathrm{HCO}_{3}\right)_{2}$ represents the water of samples of wells (W1, W4, W5, W6, $\mathrm{W} 7, \mathrm{~W} 8, \mathrm{~W} 14, \mathrm{~W} 15$ and $\mathrm{W} 16)$, reflecting the impact of direct replenishment from the nearby scarps.

3) The third assemblage comprises of: $\mathrm{NaCl}, \mathrm{MgCl}_{2}, \mathrm{CaCl}_{2}, \mathrm{CaSO}_{4}$ and $\mathrm{Ca}$ $\left(\mathrm{HCO}_{3}\right)_{2}$ which characterizes the water of sample of well (W21); it reflects the impact of marine sediments of the weathering products of El Tih Plateau.

\section{Important of the groundwater:}

SAR. pHc, adj SAR and adj $\mathbf{R}_{\mathbf{N a}}$ : according to guidelines reported by Ayers and Westcot (1976), SAR classes were no problem (less than 3), increasing problem (3 - 9), severe problem ( higher than 9). From table (2) SAR represented increasing problem except for water samples from W9 and W21 which indicated no problem and W8 indicated severe problem. Occurring relatively carbonate, an adjusted SAR (adj SAR) is recommended (Ayers and Westcot (1976).

The adj SAR. can be reduced by reducing the bicarbonate $\left(\mathrm{HCO}_{3}\right)$ level. This is normally accomplished by acidifying the irrigation water, Suarez, (1981). The adj $\mathrm{R}_{\mathrm{Na}}$ was related to the ions concentration in the irrigation water of $\mathrm{HCO}_{3}$ and $\mathrm{Ca}$ me/l, (Ayers and Westcot 1994).

- Values of pHc above 8.4 indicate a tendency to dissolve lime from the soil through which the water moves;

- values below 8.4 indicate a tendency to precipitate lime from the water applied. (Wilcox, 1966 and Rhoades, 1972)

Fayoum J. Agric. Res. \& Dev., Vol. 30, No.2, July, 2016 
TDS : Concerning the water quality for irrigation purposes, many classifications tools were applied. Data in (Table 2) showed that, TDS (g/l) of groundwater of the studied wells at Wadi Sidri ranged between $0.432 \mathrm{~g} / \mathrm{l}$ (Well W9) to $3.376 \mathrm{~g} / \mathrm{l}$ (W21) in Wadi Sidri.

Table (6): Salinity Classes of groundwater samples of the wells at Wadi Sidri .

\begin{tabular}{|c|c|c|}
\hline \multicolumn{2}{|c|}{$\begin{array}{c}\text { Water salinity classification Water salinity } \\
\text { classification } \\
\text { (as Chebotarev, 1955) }\end{array}$} & \multirow[t]{2}{*}{ Well No. } \\
\hline Class & TDS (g/l) & \\
\hline Good Portable & $(<0.50)$ & 9 \\
\hline Fresh & $(0.50-0.70)$ & -------- \\
\hline Fairly Fresh & $(0.70-1.50)$ & $\begin{array}{c}3,4,5,6,7,10,11,12,13,14 \\
15,16,17 \text { and } 20\end{array}$ \\
\hline Slightly Brackish & $(1.50-2.50)$ & $1,2,8,18$ and 19 \\
\hline Brackish & $(2.50-3.20)$ & -------- \\
\hline Definitely Brackish & $(3.20-4.00)$ & 21 \\
\hline Sligh.tsaline - Extrem.Saline & $(4.00->10.00)$ & 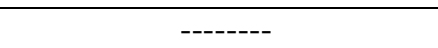 \\
\hline
\end{tabular}

As Chebotarev (1955), the presented data (Table 6), reflect that TDS of (W9) showed good portable water quality. Meanwhile, most of the studied wells have fairly fresh to slightly brackish water quality. On the other hand; TDS of (W21) showed definitely brackish water quality. This means, almost the vast majority of wells in Wadi Sidri have suitable groundwater for use in drinking and irrigation.

\section{Trace elements:}

Many traces and heavy elements are present in groundwater in low concentration (less than $0.1 \mathrm{ppm}$ ), but sometimes some of them found higher, particularly if the water has been in contact with mineralized rock or ore bodies. $\mathrm{Fe}, \mathrm{Mn}, \mathrm{Zn}, \mathrm{Cu}, \mathrm{Pb}$ and $\mathrm{Cd}$ are the most common minor components encountered in the area under consideration.

Rowe and Abdel-Magid (1995) tabulated (Table 7) the permissible limits for some trace elements and heavy metals in irrigation water, in addition to some observations must be taking before use these quality of waters for crop irrigation.

The concentrations of heavy and trace components (ppm) are tabulated in Table (8). Also, ideas about their distributions in the area under consideration are given below.

Iron $\left(\mathrm{Fe}^{++}\right)$:

Iron is one of the most minerals commonly in the earth crust. Its main sources in groundwater are the dissolution of iron-bearing minerals commonly found in well sediments as pyrite, siderite, magnetite, and iron silicate. The common form in the groundwater is the soluble ferrous ion $\left(\mathrm{Fe}^{++}\right)$. When it is

Fayoum J. Agric. Res. \& Dev., Vol. 30, No.2, July, 2016 
CHEMICAL CONSTITUENTS OF SOME WELLS.

exposed to the atmosphere, $\mathrm{Fe}^{++}$is oxidized to the insoluble ferric state $\left(\mathrm{Fe}^{+++}\right)$, which precipitates as ferric hydroxide causing a brown discoloration of the water. Corrosion of well casing and other pipes may also contribute iron to groundwater. Moreover, bacterial activities can also increase or decrease iron concentration in groundwater.

The presence of iron in drinking water leads to a metallic taste. So, the recommended maximum concentration for drinking water is $0.3 \mathrm{mg} / \mathrm{L}$ (WHO, 1988). The chemistry of iron in natural water is influenced by certain kinds of microorganisms (Hem, 1989). Sea water contains an average of $0.003 \mathrm{ppm}$ iron (Berner, 1970). On the other hand the river water contains a higher average content of iron (about $0.67 \mathrm{ppm}$ ). In the study area, iron cation in groundwater ranged between $0.005 \mathrm{ppm}$ (W13) to $0.556 \mathrm{ppm}$ (W2).

Table (7): Limits recommended for some constituents (trace elements and heavy metals) in irrigation water.

\begin{tabular}{|c|c|c|c|}
\hline \multirow{3}{*}{ Element } & \multirow{2}{*}{\multicolumn{2}{|c|}{\begin{tabular}{|c|} 
(Concentration(ppm) \\
period of use
\end{tabular}}} & \multirow{3}{*}{ Remarks } \\
\hline & & & \\
\hline & Long & Short & \\
\hline $\mathrm{Fe}$ & 5 & 20 & $\begin{array}{l}\text { - Not Toxic for plants in aerated soils, but can contribute in } \\
\text { soil acidification and in loss of essential phosphorus and } \\
\text { molybdenum. }\end{array}$ \\
\hline $\mathrm{Mn}$ & 0.20 & 10 & $\begin{array}{l}\text { - Toxic for number of crops at a few -tenth to a few } \mathrm{mg} / \mathrm{l} \text {. } \\
\text { in acid soil. }\end{array}$ \\
\hline $\mathrm{Zn}$ & 2 & 10 & $\begin{array}{l}\text { - Toxic for many plants at widely varying concentrations. } \\
\text { - Reduced toxicity at increasing } \mathrm{pH}(>6) \text { and in fine- } \\
\text { textured or organic soils }\end{array}$ \\
\hline $\mathrm{Cu}$ & 0.20 & 5 & - Toxic for number of plants at 0.1 to $1.0 \mathrm{mg} / \mathrm{l}$ in solutions. \\
\hline $\mathrm{Pb}$ & 5 & 10 & - Can inhibit plant growth at very high concentrations. \\
\hline $\mathrm{Cd}$ & 0.01 & 0.05 & $\begin{array}{l}\text { - Toxic for bean, beets and turnips at }<0.1 \mathrm{mg} / \mathrm{l} \text { in solution. } \\
\text { - Severe conservative limits recommended. }\end{array}$ \\
\hline
\end{tabular}

\section{Manganese $\left(\mathrm{Mn}^{++}\right)$:}

Manganese resembles iron in its chemical behavior and in its occurrence in natural water. It is arises from soils and sediments due to the manganese oxides and hydroxides are common sources of manganese in soil and sedimentary rocks. Metamorphic and sedimentary rocks and mica biotite and amphibole hornblend minerals contain large quantities of manganese.

Manganese is an essential element in plant metabolism and its organic circulation can influence its occurrence in natural water. In natural water, manganese concentration is usually under $0.2 \mathrm{ppm}$, where as groundwater possesses over $10 \mathrm{ppm}$. The divalent ion $\left(\mathrm{Mn}^{++}\right)$is soluble and found in most groundwater at concentrations less than those of ferrous ion $\left(\mathrm{Fe}^{++}\right)$. The recommended maximum of manganese concentration for public water supplies set at $0.05 \mathrm{mg} / \mathrm{L}$ (WHO, 1988), and the maximum limit is $0.5 \mathrm{ppm}$

Fayoum J. Agric. Res. \& Dev., Vol. 30, No.2, July, 2016 
(Cox 1964). In the study area, $\mathrm{Mn}$ - concentration ranged between $0.001 \mathrm{ppm}$ (W14) to $0.026 \mathrm{ppm}$ (W2).

Table (8): The concentrations of heavy and trace components (ppm) in some selected wells at Wadi Sidri, (Note: N.D : $<0.0001$ ppm).

\begin{tabular}{|c|c|c|c|c|c|c|}
\hline Well No. & Fe & Mn & $\mathbf{Z n}$ & $\mathbf{C u}$ & $\mathbf{P b}$ & $\mathbf{C d}$ \\
\hline 2 & 0.556 & 0.026 & 0.012 & 0.033 & 0.037 & 0.007 \\
\hline 3 & 0.381 & 0.008 & 0.014 & 0.015 & 0.037 & 0.010 \\
\hline 5 & N.D & N.D & 0.074 & 0.011 & 0.038 & 0.011 \\
\hline 7 & 0.175 & N.D & 1.764 & 0.008 & 0.084 & 0.016 \\
\hline 11 & N.D & N.D & 0.024 & 0.019 & 0.077 & 0.015 \\
\hline 13 & 0.005 & N.D & 0.025 & 0.020 & 0.052 & 0.014 \\
\hline 14 & 0.046 & 0.001 & 0.027 & 0.007 & 0.047 & 0.010 \\
\hline 16 & 0.006 & N.D & 0.040 & 0.010 & 0.029 & 0.004 \\
\hline 19 & N.D & N.D & 0.035 & 0.019 & 0.074 & N.D \\
\hline 21 & N.D & N.D & 0.032 & N.D & 0.053 & N.D \\
\hline
\end{tabular}

$\operatorname{Zinc}\left(\mathbf{Z n}^{++}\right)$:

Zinc is one of the most abundant elements in the Earth's crust. The most exploited zinc ore is sphalerite. Zinc is an essential mineral of exceptional biologic and public health importance. In children zinc deficiency causes growth retardation and many other diseases. On the other hand, excess zinc can be harmful. Excessive absorption of zinc suppresses copper and iron absorption.

The free zinc ion in solution is highly toxic to plants, invertebrates, and even vertebrate fish. The U.S. Food and Drug Administration (FDA) have stated that zinc damages nerve receptors in the nose, which can cause anosmia (Wikipedia site, 2011). In the study area, zinc concentration ranged between $0.012 \mathrm{ppm}$ (W2) to $1.764 \mathrm{ppm}(\mathrm{W} 7)$.

Copper $\left(\mathrm{Cu}^{++}\right)$:

Most copper minerals are relatively insoluble and hence little copper is found in natural water. However, $\mathrm{Cu}^{++}$may be present in water from disintegration and weathering of rocks containing the element. Also, copper is available to surface water and groundwater, due to the extensive use of agricultural pesticides sprays containing copper compounds. It is an essential element in human metabolism, but can cause anemia, disorders of bone and connective tissue, and liver damage at excessive levels.

The toxicity of $\mathrm{Cu}^{++}$depends upon the hardness and $\mathrm{pH}$ of the water, and therefore, it is more toxic in soft water and in water with low alkalinity (Jones, 1964). Drinking water should not have more than $1 \mathrm{mg} / \mathrm{L} \mathrm{Cu}^{++}$. The concentration of $\mathrm{Cu}^{++}$at levels more than $0.5 \mathrm{mg} / \mathrm{L}$ is usually attributed to the use of $\mathrm{Cu}^{++}$salts for the control of algae and other aquatic growths (Rainwater and Thatcher, 1960). In the study area, copper concentration ranged between 0.007 ppm (W14) and 0.033 ppm (W2).

Fayoum J. Agric. Res. \& Dev., Vol. 30, No.2, July, 2016 
Lead $\left(\mathbf{P b}^{++}\right)$:

Lead is one of the minor elements in natural water. It is an accumulative poison to human and animals, but the individual sensitivity differs. $\mathrm{Pb}^{++}$concentration in natural water is limited and controlled by the solubility restrictions. It is commonly occurred as lead sulphide (Galena), and lead sulphate.

The lead toxicity appears to be greater in soft water than in hard water (Pickering and Henderson, 1960). The use of lead by humans tended to disperse the element widely through the environment. The concentration of $\mathrm{Pb}^{++}$in rain and river waters ranges from $0.1 \mathrm{mg} / \mathrm{L}$ or more to $0.001 \mathrm{mg} / \mathrm{L}$ or less in more remote areas (Lazrus et al., 1970). The natural mobility of lead is low owing to the low solubility of lead hydroxy carbonate and phosphate (Nriagu, 1974). Also, the adsorption of lead on organic and inorganic sediment surfaces and coprecipitation of lead with manganese oxide tend to maintain low concentration levels in surface water and groundwater (Hem, 1989). In the study area, Lead concentration ranged between $0.029 \mathrm{ppm}$ (W16) and $0.084 \mathrm{ppm}$ (W7).

Cadmium $\left(\mathbf{C d}^{++}\right)$:

Generally, cadmium is present in zinc ore minerals such as sphalerite, and is recovered from some copper ores during smelting and refining. It is rarely found in natural water. Many uses of $\mathrm{Cd}^{++}$in industry tend to make the element available to water, that comes in contact with buried wastes, where $\mathrm{Cd}^{++}$compounds are used in the production of plastic pipes, metal plating, printing ink, and storage battery manufacture. Cadmium is considered to be toxic if its concentration exceeds $0.01 \mathrm{mg} / \mathrm{L}$ both in drinking and irrigation water (Hem, 1989). In the study area, cadmium concentration ranged between $0.004 \mathrm{ppm}$ (W16) and $0.016 \mathrm{ppm}$ (W7).

\section{Acknowledgment}

The author would like to acknowledge Head Res. Prof. Doctor Tarek Abdel Raman Abou El-Defan for helpful support samples and the comment of this paper.

\section{REFERENCES}

Ayers, R.S. and Westcot, D. W. (1976). Water Quality for Agriculture. FAO Irrigation and Drainage Paper No, 29 (Rev 1), Food and Agriculture Organization (FAO) of the United Nations.

Ayers, R.S., and Westcot, D.W. (1994). Water quality for agriculture. (FAO) Handbook 29.

Berner, R., (1970): Abundance of natural water. Wedepohl, K. H. (Exceptive Edit.), Handbook of Geochemistry, SprengerVerlage, Berlin

Chapman, H.D. and Pratt, P. E. (1961). Methods for Analysis of Soils, Plants and Waters. Univ. of Calif, Div. of Agric. Sci.

Fayoum J. Agric. Res. \& Dev., Vol. 30, No.2, July, 2016 
Chebotarev, I. (1955). Metamorphism of natural waters in the crust of earth. I. Geochem. Cosmochem. Acta, 8, 22.

Cox, C. R., (1964). Operation and control of water treatment processes. Monograph Series No. 49, World Health Organization, Geneva, Switzerland, $390 \mathrm{pp}$.

Geological Survey, U. S. (GSUS), (1998). Preliminary Results of the National Water Quality Assessment Program (NAWQA). VOC National Synthesis Project.

Hem, J.D. (1970). Study and Interpretation of the chemical characteristics of natural water. Second Ed. U. S. Geol. Survey water supply paper 1473, $363 \mathrm{pp}$.

Hem, J.D. (1989). Study and Interpretation of the chemical characteristics of natural water. Second Ed. U. S. Geol. Survey water supply paper 2254, third printing , $264 \mathrm{pp}$.

Jones, J. R., (1964). Fish and River Pollution. London, Butterworth.

Lazrus, A. L., Lorange, E. and Lodge, J. B., (1970). Lead and other metal ions in U. S. precipitation. Environmental Sci. and Technology, Vol. 4, pp. 55-58.

Nriagu, J. O. (1974). Lead orthophosphates. IV. Formation and stability in the environment. Geochemica et CosmochemicaActa, Vol. 38, P. 887-898.

Pickering, Q. H. and Henderson, C., (1960). The aqutetoxicity of some heavy metals to different species of warm water fishes. International Journal of Air- water Pollution, Vol. 10, pp. 453-463.

Rainwater, F.H. and Thatcher, H. (1960). Methods of collection and analysis of water samples .Geol. Survey Water supply paper, No., 1454, Washington.

Rhoades, J. D. (1972). Quality of water for irrigation. Soil Science 113: 277 284

Rowe, D. and Abdel-Magid (1995). Handbook of waste water reclamation and Reuse CRC press, Inc. $550 \mathrm{pp}$.

Soltanpour, P.N. (1985). Use of $\mathrm{NH}_{4} \mathrm{HCO}_{3}$-DTPA soil test to evaluate elemental availability and toxicity. Community in Soil Sci. and plant analysis. 13 (3): 323-338.

Suarez, D. L. (1981). Relation between pHc and Sodium Adsorption Ratio (SAR) and an alternative method of estimating SAR of soil drainage waters. Soil Sci. Soc. Am J. 45:469-475

Wilcox, L.V. (1966). Tables for calculating the pHc values of waters. US Salinity laboratory Mimeo Report, B p.

Wikipedia site, (2011). Wikipedia, the free encyclopedia, last modified on 23 September 2011 at 03:32.

Fayoum J. Agric. Res. \& Dev., Vol. 30, No.2, July, 2016 
World Health Organization (WHO) (1988). World Health Organization assessment of fresh water quality. Report on the results of the WHO/UNEP program on Health -Related Environmental Monitoring U.N Environment Program., pp: $24-32$.

المكونات الكيميائية للمياه الجوفية لبعض الآبار في سيناء (مصر) ومدى ملاءمتها للأنشطه المختلفه لمأستخدام

مصطقى محمود شون* وعزه راشد عبد الحميد**

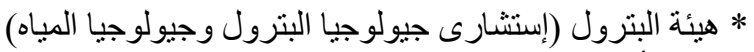

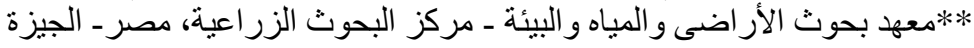

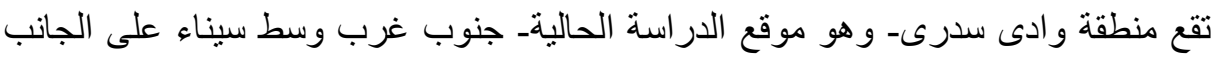

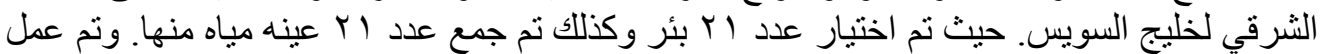

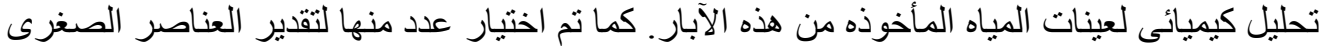

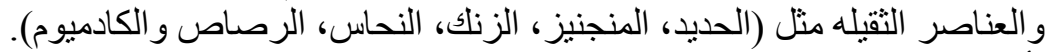

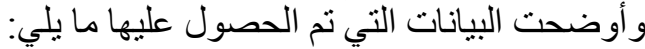

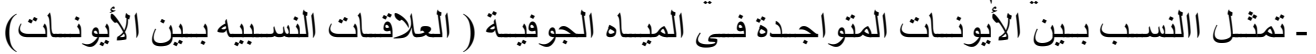

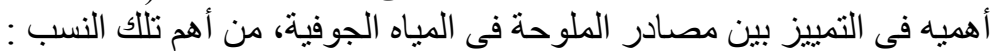
. $(\mathrm{Na}+\mathrm{K}) / \mathrm{Cl},(\mathrm{SO} 4 / \mathrm{Cl}),(\mathrm{Ca} / \mathrm{Mg})$ and $(\mathrm{Na} / \mathrm{K})$

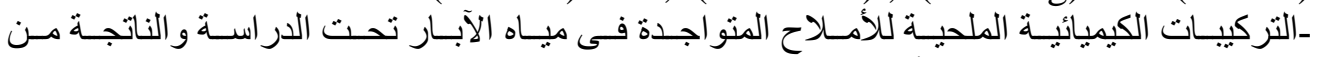

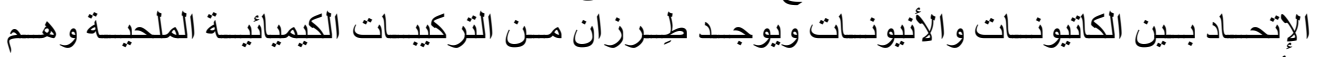

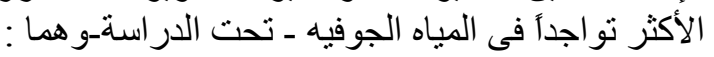

مجمو عه مكونه من : و وجمو عهاه مكونه من :

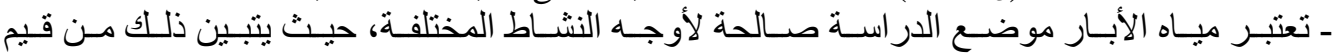

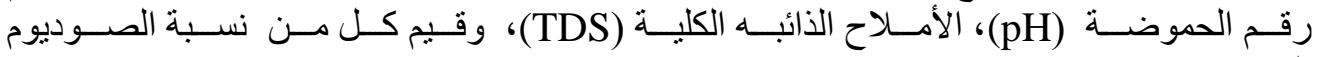

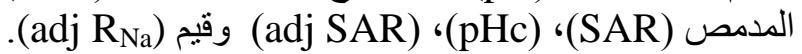

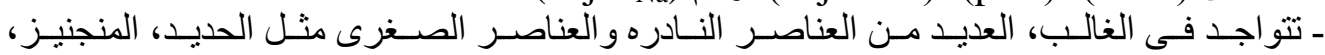

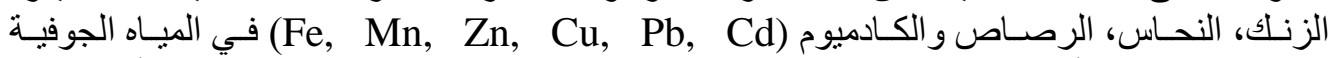

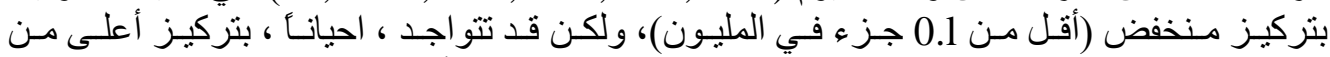
ذللك بكثير، خصوصا إذا كان الماء في تلامس مع المعادن الصخرية أو خامات المن المعادن.

Fayoum J. Agric. Res. \& Dev., Vol. 30, No.2, July, 2016 